\title{
Anacardiaceae-feeding Nepticulidae in the Neotropics: description of Stigmella lilliputica sp. nov. from Argentina, a pest on Chilean peppertree Schinus polygama
}

\author{
Jonas Rimantas Stonis ${ }^{1^{*}}$, \\ Andrius Remeikis ${ }^{2}$ \\ ${ }^{1}$ Lithuanian University of Educational \\ Sciences and Baltic-American \\ Biotaxonomy Institute, \\ Studentu St. 39, \\ Vilnius 08106, Lithuania \\ ${ }^{2}$ Institute of Ecology, \\ Nature Research Centre, \\ Akademijos St. 2, \\ Vilnius 08412, Lithuania
}

\begin{abstract}
The paper deals with a description of a new leaf-mining Nepticulidae species, Stigmella lilliputica Remeikis \& Stonis, sp. nov., from Argentina, the larvae of which feed on leaves of the Chilean peppertree Schinus polygama (Cav.) Cabrera. The species is illustrated with photographs of the adults and leaf mines, a distribution map as well as drawings and photographs of the genitalia.
\end{abstract}

Keywords: Anacardiaceae, leaf mines, Nepticulidae, new species, Schinus L.

\section{INTRODUCTION}

The family Nepticulidae (pygmy moths) has been characterized in monographic reviews by Johansson et al. (1990) and Puplesis (1994) and, with special reference to South America, by Puplesis, Robinson (2000) and Stonis et al. (2016).

Larvae of pygmy moths mine during all instars, feed inside leaves, and occasionally other green tissues of plants. The vast majority of the species are monophagous or strictly oligophagous. Therefore, studies of feeding preferences of these specialized leaf-mining insects are a priority goal.

As regards the Neotropical species, extensive studies of their trophic relationships started only recently. It is known that a vast majority of the Neotropical Nepticulidae are trophically associated with either Asterids or Rosids. As a result of

\footnotetext{
*Corresponding author. Email: stonis@leu.lt
}

the preliminary analysis by Remeikis et al. (2016), the Nepticulidae feeding on Asteraceae plants, in contrast to the Holarctic fauna, were recorded for some $24 \%$ of the trophically investigated taxa; on Rosaceae, for about 15\%; on Lamiaceae, 13\%; on Fagaceae, 9\%; on Euphorbiaceae, 5\%; on Fabaceae and Malvaceae, about 4\% (each); on Urticaceae, 3\%; on Polygonaceae, Melostomataceae, and Ericaceae, 2.5\% (each); and on Grossulariaceae, Salicaceae, Rhamnaceae, Myrtaceae, Scrophularia ceae, and Verbenaceae, nearly 2\% (each). Some Nepticulidae were also found on Gunneraceae, Geraniaceae, Meliaceae, Rubiaceae, and Boraginaceae (almost 1\% each) (Remeikis et al., 2016). There are also species trophically associated with Anacardiaceae (though very few). It should be noted that the percentages counted by Remeikis et al. (2016) include only two (not three) Anacardiaceae-feeding species out of the currently known three species listed in Fig. 1. The host-plant 
family Anacardiaceae (the sumac family) comprises about 78 genera and more than 700 species of evergreen or deciduous trees, shrubs, and woody vines (Mitchell, 2004). The family is native to tropical and subtropical areas, with several species occurring in temperate regions. The primary centres of diversity are in Mexico, South America, southern and equatorial Africa, and South East Asia (Mitchell, 2004).

During the course of the present study, we examined large samples of reared Nepticulidae material from Central and South America, including some material collected by Danish entomologists in 1981 in the biogeographical province of Monte (Argentina). Our study revealed one species associated with the host plant from the Anacardiaceae family (which is described in the current paper).

\section{MATERIALS AND METHODS}

The description of the new species is based on material deposited in the collection of the Zoological Museum, Natural History Museum of Denmark in Copenhagen, Denmark, which was collected in Argentina in 1981 by E. S. Nielsen and Ole Karsholt during the international expedition Mision Cientifica Danesa. Collecting methods and protocols for species identification and description are outlined in Puplesis, Robinson (2000) and Stonis et al. (2016). After maceration of the abdomen in $10 \% \mathrm{KOH}$ and subsequent cleaning, male genital capsules were removed from the abdomen and mounted ventral side uppermost. The phallus was removed and mounted in Euparal separately but on the same genitalia slide. Abdominal pelts and female genitalia were stained with Chlorazol Black (Direct Black 38/ Azo Black) (for a detailed description of the method, see Stonis et al., 2014).

Permanent slides were photographed and studied using a Leica DM2500 microscope and Leica DFC420 digital camera. The descriptive terminology of morphological structures follows Puplesis, Robinson (2000), except for the term "aedeagus", which is referred here as "phallus", and the term "cilia", which is referred here as "fringe".
Institutional abbreviation used in the text: ZMUC - Zoological Museum, University of Copenhagen.

\section{RESULTS}

\section{Stigmella lilliputica Remeikis \& Stonis, sp. nov.}

Type material. Holotype: $\curvearrowright$, ARGENTINA, Rio Negro, $50 \mathrm{~km}$ E of Choele Choel, caught around Schinus polygama (Cav.) Cabrera, elevation ca. 170 m, 13.ix.1981, E. S. Nielsen $\&$ O. Karsholt, genitalia slide no. RA584 $\widehat{ }$ (ZMUC). Paratypes: 5 ふै, 2 ㅇ, same label data, genitalia slide nos. RA585 9 , RA588 $\widehat{\circ}$, RA631 $\widehat{\jmath}$, RA632 $\hat{O}$ (ZMUC). Additional examined material: a collection of leaf-mine samples, same label as paratypes (ZMUC).

Diagnosis. In the male genitalia, the combination of a small U-shaped gnathos, very long apical process of valva, and a pair of spine-like cornuti distinguishes $S$. lilliputica sp. nov. from all other Stigmella. The host plant (Schinus polygama) also makes this species distinctive.

Male (Fig. 2). Forewing length about $1.8 \mathrm{~mm}$; wingspan about $4.1 \mathrm{~mm}$. Head: palpi and face almost white; frontal tuft dark grey-brown on vertex, pale orange to cream white on frons; collar brownish cream; scape white, glossy; antenna longer than half the length of forewing; flagellum with about 39 segments, grey to dark grey. Thorax and tegula grey, with some fuscous scales anteriorly; forewing grey, at certain angle some scales grey-white or cream white tipped; fascia of forewing postmedian, wide, comprised of grey-white, non-shining scales; the narrow area before fringe and forewing's apex black-brown; fringe grey to almost white; underside of forewing grey-brown, without spots. Hindwing grey to pale grey on upper side and underside, without spots or androconia; fringe grey. Legs cream grey, with fuscous scales on upper side. Abdomen black-grey on upper side, dark grey on underside; genital segments grey; anal tufts short, indistinctive, dark grey.

Female (Fig. 3). Forewing length $1.6-1.7 \mathrm{~mm}$; wingspan $3.9-4.0 \mathrm{~mm}$. Antenna shorter than half the length of forewing, usually curved (number 


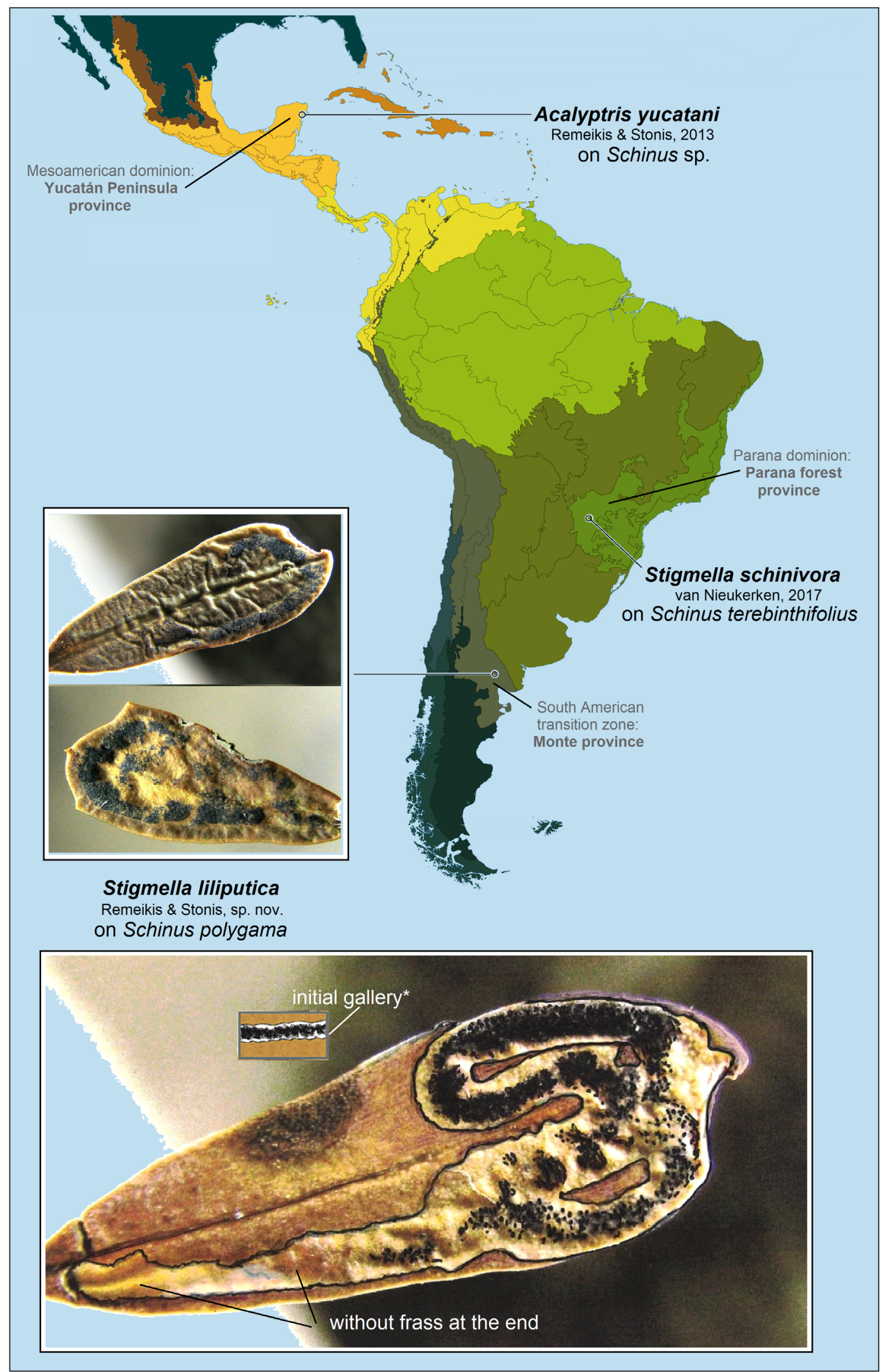

Fig. 1. Leaf mines of Stigmella lilliputica Remeikis \& Stonis, sp. nov. on Schinus polygama, Monte province, Argentina ( ${ }^{*}$ possibly the initial gallery starts in a leaf vein) 


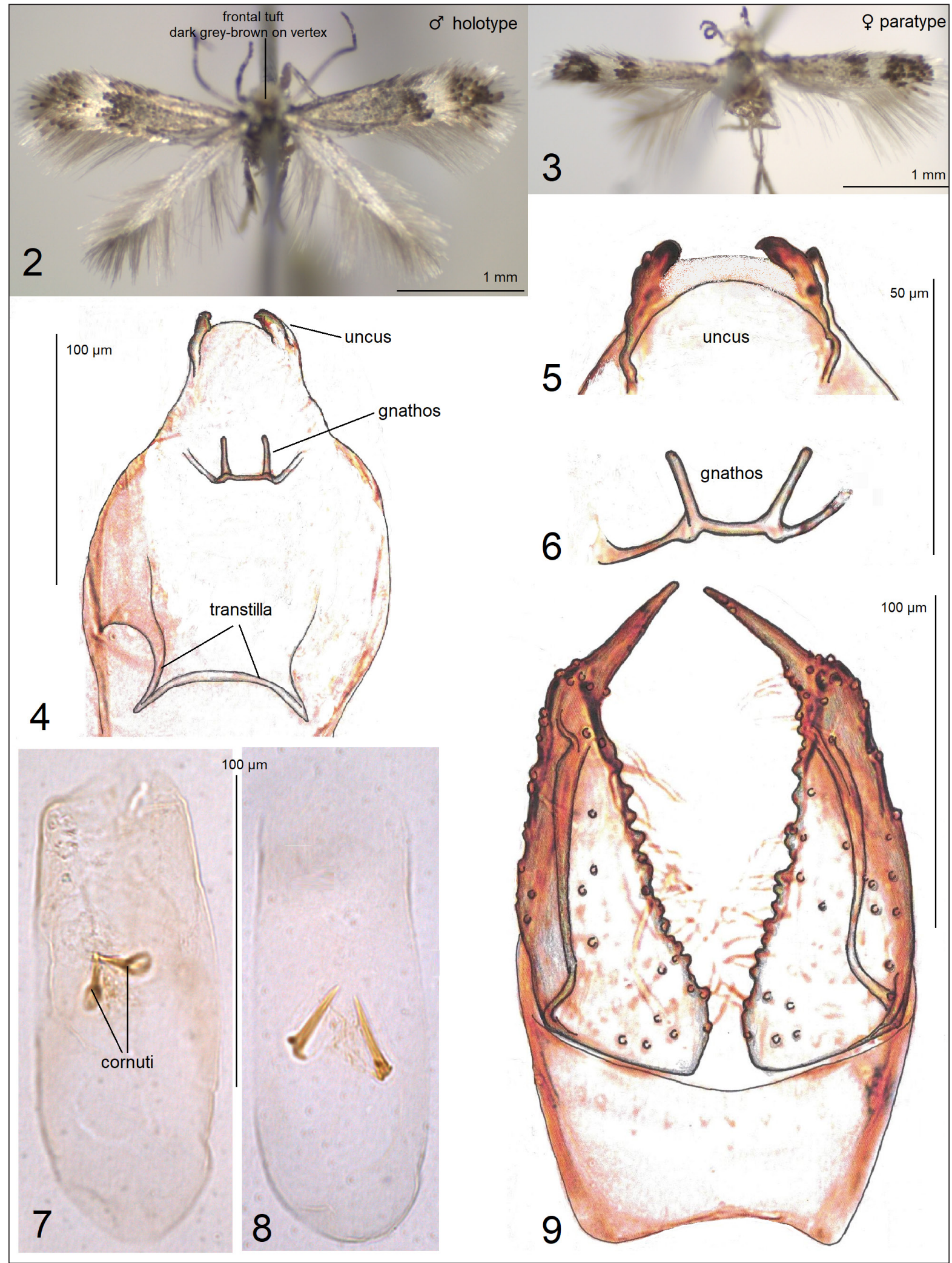

Figs. 2-9. Stigmella lilliputica Remeikis \& Stonis, sp. nov. 2 - male adult, holotype; 3 - female adult, paratype; 4 - male genitalia, dorsal view of capsule, slide no. RA584, holotype; 5, 6 - same, uncus and gnathos, genitalia slide no. RA588, paratype; 7 - same, phallus, genitalia slide no. RA588, paratype; 8 - same, slide no. RA584, holotype; 9 - same, ventral view of capsule, slide no. RA588, paratype (ZMUC) 
of segments unknown). At certain angle of view, base of forewing with distinctly cream-tipped scales. Abdomen dark grey on upper side, grey cream on underside. Otherwise as in male.
Male genitalia (Figs. 4-15). Capsule longer $(190-205 \mu \mathrm{m})$ than wide $(115-125 \mu \mathrm{m})$. Uncus (Figs. 4, 5, 13, 14) thickened only laterally. Gnathos very small (Figs. 11, 12), U-shaped

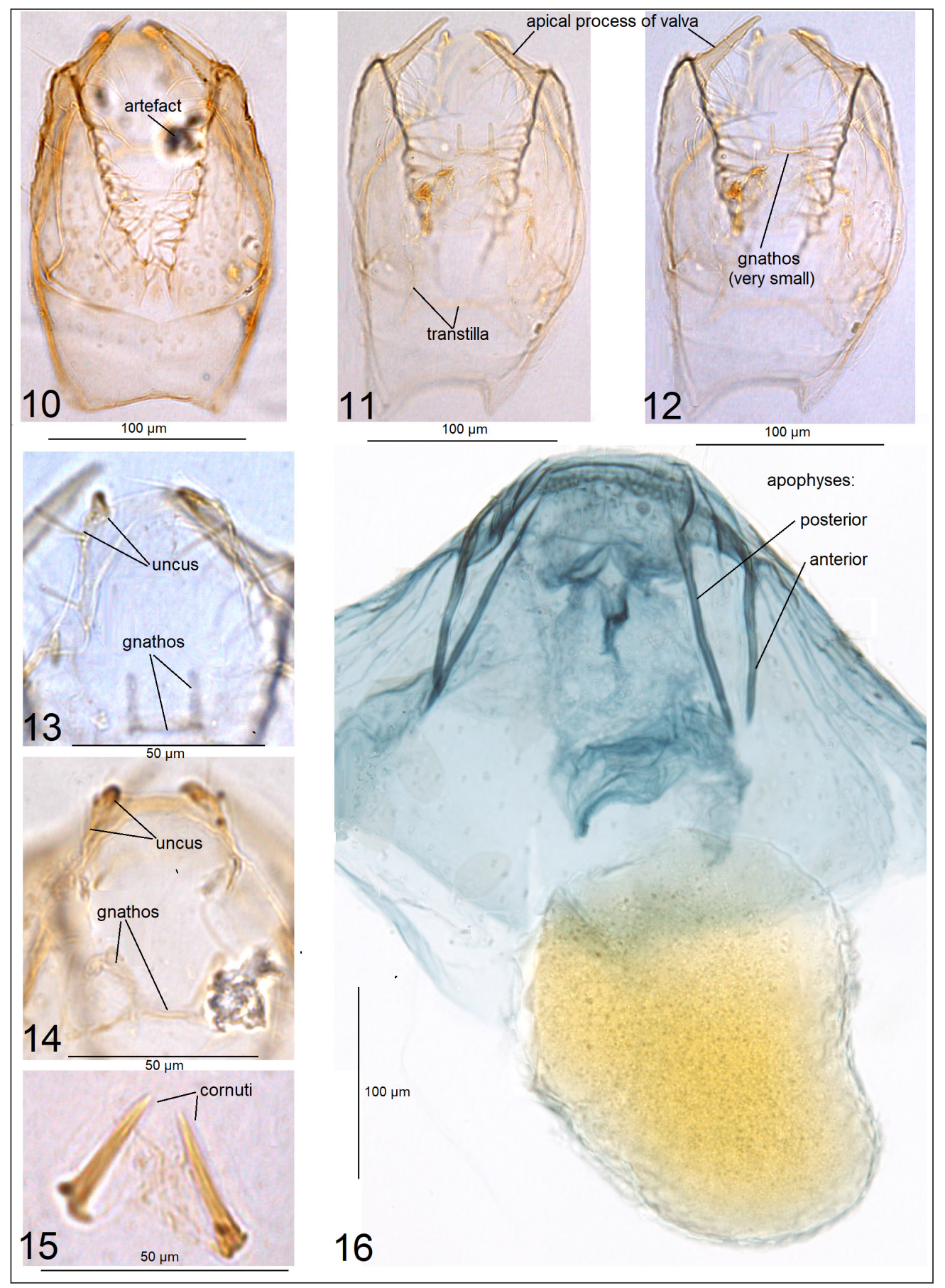

Figs. 10-16. Genitalia of Stigmella lilliputica Remeikis \& Stonis, sp. nov. 10 - male genitalia, ventral view of capsule, slide no. RA588, paratype; 11, 12 - same, slide no. RA584, holotype; 13 - same, uncus and gnathos, slide no. RA584, holotype; 14 - same, slide no. RA588, paratype; 15 - same, cornuti, slide no. RA584, holotype; 16 - female genitalia, slide no. RA585 (ZMUC) 
(Figs. 4, 6). Valva (Fig. 9) 140-150 $\mu \mathrm{m}$ long, $35-40 \mu \mathrm{m}$ wide, with very large apical process (Fig. 11, 12); transtilla (Figs. 4, 11) with triangular sublateral processes. Vinculum with shallow anterior excavation and weakly developed lateral lobes. Phallus (Figs. 7, 8) 145-150 $\mu \mathrm{m}$ long, $60 \mu \mathrm{m}$ wide; vesica with two $30 \mu \mathrm{m}$ long spine-like cornuti (Fig. 15).

Female genitalia (Fig. 16). Total length about $440 \mu \mathrm{m}$. Abdominal apex wide, distinctly truncate. Anterior and posterior apophyses slender. Vestibulum relatively wide, without sclerites. Accessory sac indistinctive. Ductus spermathecae probably broken (missing) in Fig. 16. Corpus bursae oval-shaped, $235 \mu \mathrm{m}$ long, $190 \mu \mathrm{m}$ wide; pectinations indistinctive or absent (not visible in slide no. RA585; Fig. 16).

Bionomics (Fig. 1). Host plant: Schinus polygama (Cav.) Cabrera (Anacardiaceae). Judging from the collected empty leaf mines, larva mines in leaf of Chilean peppertree in August. Egg on upper side or underside of the leaf blade, usually on mid vein, sometimes on lateral vein of the leaf. Leaf mine (Fig. 1) as a sinuous or contorted gallery with a line of black frass; frass fills about $2 / 3$ of the width of the gallery. It is supposed that the gallery starts inside the leaf vein. Larval exit slit on upper side of the leaf. Adults fly in September.

Distribution (Figs. 1). This species occurs in Argentina (Monte biogeographical province of South American transition zone) at altitudes about $170 \mathrm{~m}$.

Etymology. The species is named after Lilliputians, miniature people from Gulliver's Travels by Jonathan Swift in reference to the small size of the adults and particularly because of the unusually miniature gnathos in the male genitalia.

Remarks. The host plant Schinus polygama (the Chilean peppertree or Hardee peppertree) is native to Argentina and Chile and naturalized (invasive) in California.

\section{DISCUSSION}

Currently three species of Anacardiaceae-feeding Nepticulidae are known from the Neotropics. Along with our Stigmella lilliputica, another
South American species, Stigmella schinivora, was described and illustrated by the Dutch researcher E. J. van Nieukerken (van Nieukerken et al., 2016) on the basis of his material collected in August 2000 in Cataratas del Iguazú, Argentina. The third species, Acalyptris yucatani Remeikis \& Stonis was described and illustrated from a single female specimen collected in Central America, the Yucatán peninsula province (Stonis et al., 2013) (Fig. 1). The host plants of all three currently known Nepticulidae species feeding on Anacardiaceae belong to a single genus (Schinus L.). The plants of this genus are well represented in the flora of the Neotropics and are commonly known as peppertrees; it is the only genus occurring naturally above 3,000 meters (Mitchell, 2004). Some species of Schinus may become invasive outside their natural habitats. Schinus polyga$m a$, a newly recorded host plant of Stigmella lilliputica sp. nov., is an expanding invasive plant outside its natural range, e.g., in California, USA (The Global Invasive Species Team, 2009).

In tropical America, there are about 33 genera and 170 species of Anacardiaceae plants, including the largest genus, Rhus, with 25 species solely from tropical America (Mitchell, 2004). Rhus, along with few other Anacardiaceae genera, such as Pistacia, Cotinus, etc., has been confirmed as a host plant for few Nepticulidae species in boreal regions (see the Catalogue of Nepticuloidea by Diškus, Puplesis, 2003). At least two species of Rhus-feeding Stigmella (Nepticulidae) are described from Nearctic America (Newton, Wilkinson, 1982); in total, the fauna of the Nearctics and Palaearctics counts at least six Anacardiaceaefeeding species (Diškus, Puplesis, 2003).

Drawing on the great diversity of potential Anacardiaceae host plants in tropical and subtropical America, we suppose that the Anacardiaceae-feeding Nepticulidae fauna is much richer than is presently known. So far, in the Neotropics, the Nepticulidae trophically associated with Anacardiaceae account for about $1 \%$ of the currently described and pending for description trophically investigated taxa (including our own field records of purely leaf mines without reared adults). 
It is interesting to note that recent surveys in southern Florida, USA, Brazil, and Argentina carried out with the purpose of assisting biological control agents to deal with the invasive Brazilian peppertree Schinus terebinthifolius have revealed four previously unknown species and one new genus of another Lepidopteran family of leaf miners, Gracillariidae (Davis et al., 2011).

\section{ACKNOWLEDGEMENTS}

The authors are indebted to Ole Karsholt and the late Professor N. P. Kristensen (ZMUC) for the initial stimulus to start the Neotropical project together with generous support during its course as well as the loan of the Neotropical material. This study was partially supported by the Research Foundation of the Lithuanian University of Educational Sciences (2017).

Received 11 August 2017 Accepted 13 September 2017

\section{References}

1. Davis DR, Mckay F, Oleiro M, Vitorino MD, Wheeler GS. Biology and systematics of the leafmining Gracillariidae of Brazilian pepper tree, Schinus terebinthifolius Raddi, with descriptions of a new genus and four new species. J Lepid Soc. 2011; 65(2): 61-93.

2. Diškus A, Puplesis R. Catalogue of the world Nepticuloidea \& Tischerioidea. In: Puplesis R, Diškus A, editors. The Nepticuloidea \& Tischerioidea (Lepidoptera) - a global review, with strategic regional revisions. Lutute Publishers, Kaunas, 2003; p. 18-436.

3. Johansson R, Nielsen ES, van Nieukerken EJ, Gustafsson B. The Nepticulidae and Opostegidae (Lepidoptera) of North West Europe. Fauna Entomol Scand. 1990; 23(1/2): 1-739.

4. Mitchell JD. Anacardiaceae. In: Smith N, Mori SA, Henderson A, Stevenson DWm, Heald SV, editors. Flowering plants of the Neotropics. Oxford, Princeton University Press. 2004; 594 p.
5. Newton PJ, Wilkinson C. A taxonomic revision of the North American species of Stigmella (Lepidoptera: Nepticulidae). System Entomol. 1982; 7(4): 367-463.

6. Puplesis R. The Nepticulidae of Eastern Europe and Asia: western, central and eastern parts. Leiden: Backhuys Publishers; 1994. $291 \mathrm{p}$.

7. Puplesis R, Robinson GS. A review of the Central and South American Nepticulidae (Lepidoptera) with special reference to Belize. Bull Nat Hist Mus Entomol. 2000; 69(1): 3-114.

8. Remeikis A, Diškus A, Stonis JR. Preliminary trophic analysis of leaf-mining Nepticulidae: pronounced feeding strategies in Middle and South America? Biologija. 2016; 62(4): 207-14.

9. Stonis JR, Diškus A, Remeikis A, Gerulaitis V, Karsholt O. Leaf-mining Nepticulidae (Lepidoptera) from record high altitudes: documenting an entire new fauna in the Andean páramo and puna. Monograph. Zootaxa. 2016; 4181(1): 1-94.

10. Stonis JR, Diškus A, Remeikis A, Navickaite A. Study methods of Nepticulidae: micro-mounts of genitalia structures. In: Stonis JR, Hill SR, Diškus A, Auškalnis T, editors. Selected abstracts and papers of the First Baltic International Conference on Field Entomology and Faunistics. Vilnius: Edukologija Publishers; 2014. p. 32-35.

11. Stonis JR, Remeikis A, Diškus A, Noreika R. New Nepticulidae species (Insecta, Lepidoptera) from the Yucatán Peninsula (SE Mexico). Zootaxa. 2013; 3609(2): 223-30.

12. The Global Invasive Species Team. Schinus polygamus (Cav.) Cabrera (Peruvian peppertree). https://www.invasive.org/gist/alert/ alrtschi.html. Updated March 2009. Retrieved 29 July 2017.

13. Van Nieukerken EJ, Doorenweerd C, Nishida K, Snyers C. New taxa, including three new genera, show uniqueness of Neotropical Nepticulidae (Lepidoptera). ZooKeys. 2016; 628: $1-63$. 
Jonas Rimantas Stonis, Andrius Remeikis

PIETŲ AMERIKOS MAŽIEJI GAUBTAGAL-

VIAI (NEPTICULIDAE), TROFIŠKAI SUSIJĘ

SU ANACARDIACEAE: NAUJOS RŪŠIES

STIGMELLA LILLIPUTICA, MINUOJANČIOS

SCHINUS POLYGAMA LAPUS, APRAŠYMAS

Santrauka

Straipsnyje pateikti naujausi Pietų Amerikos Anacardiaceae augalus minuojančių mažųjų gaubtagalvių (Nepticulidae) tyrimų rezultatai ir aprašoma viena nauja mokslui rūšis - Stigmella lilliputica Remeikis \& Stonis, sp. nov. Ši Argentinoje aptinkama rūšis pasižymi išskirtine genitalinių struktūrų morfologija ir yra plintančio invazinio Schinus polygama (Cav.) Cabrera minuotoja. Iš viso šiuo metu registruotos trys mažųjų gaubtagalvių rūšys, kurios Vidurio ir Pietų Amerikoje minuoja Anacardiacae augalus.

Raktažodžiai: Anacardiaceae, lapų minuotojai, mažieji gaubtagalviai, naujos rūšys, Nepticulidae, Schinus L. 